\title{
Treatment of high-strength ethylene glycol waste water in an expanded granular sludge blanket reactor: use of PVA-gel beads as a biocarrier
}

\author{
Yue Jin ${ }^{1}$, Dunqiu Wang ${ }^{2,3}$ and Wenjie Zhang ${ }^{2,3^{*}}$
}

\begin{abstract}
Industrial-scale use of polyvinyl alcohol (PVA)-gel beads as biocarriers is still not being implemented due to the lack of understanding regarding the optimal operational parameters. In this study, the parameters for organic loading rate $(O L R)$, alkalinity, recycle rate, and addition of trace elements were investigated in an expanded granular sludge blanket reactor (EGSB) treating high-strength ethylene glycol wastewater (EG) with PVA-gel beads as biocarrier. Stable chemical oxygen demand (COD) removal efficiencies of $95 \%$ or greater were achieved, and continuous treatment was demonstrated with appropriate parameters being an OLR of $15 \mathrm{~kg} \mathrm{COD} / \mathrm{m}^{3} /$ day, $\mathrm{NaHCO}_{3}$ added at $400 \mathrm{mg} / \mathrm{L}$, a recycle rate of $15 \mathrm{~L} / \mathrm{h}$, and no addition of trace elements addition. A biogas production yield rate of $0.24 \mathrm{~m}^{3} / \mathrm{kg}$ COD was achieved in this study. A large number of long rod-shaped bacteria (Methanosaeta), were found with low acetate concentration in the EGSB reactor.
\end{abstract}

Keywords: Anaerobic, Cost, Methanosaeta, Methanosarcina

\section{Background}

Ethylene glycol is widely used as a raw material in industrial processes, and many of these processes discharge high-strength ethylene glycol wastewater (EG). Usually a biological process is suggested in treating EG, and good removal performance was achieved with an influent chemical oxygen demand (COD) range between 1000 and $3000 \mathrm{mg} / \mathrm{L}$ (Hassania et al. 2014). Despite this, an anaerobic treatment method is preferred due to its simplicity, reduced sludge production and lower power consumption. The formation of microbial granules is a key factor for successful operation of an anaerobic reactor; however, granule formation when treating EG fails to occur (Hulshoff Pol et al. 2004), thus EG treatment plants generally operate with a reduced organic loading rate (OLR).

\footnotetext{
*Correspondence: zhangwj_zhangwj@hotmail.com

${ }^{2}$ Guangxi Key Laboratory of Environmental Pollution Control Theory and Technology, Guilin University of Technology, Guilin 541004, China Full list of author information is available at the end of the article
}

Polyvinyl alcohol (PVA)-gel beads are thought to be suitable candidate carriers (Wenjie 2008a; Wenjie et al. 2011; Khanh et al. 2011). Wenjie et al. (2009) used cultivated PVA-gel beads to seed a lab-scale anaerobic fluidized bed reactor treating corn steep liquor, and a removal efficiency of $91 \%$ was achieved at an OLR of $27.5 \mathrm{~kg}$ $\mathrm{COD} / \mathrm{m}^{3} /$ day. Wenjie et al. (2011) used PVA-gel beads in an upflow anaerobic sludge blanket (UASB) reactor to treat EG, and successful treatment performance was achieved with addition of sufficient trace elements. The results obtained from the aforementioned studies indicated that PVA-gel beads could display good performance in EG treatment. However, industrial-scale implementation has not occurred due to the lack of understanding of the optimal operational parameters, which are necessary for design.

In this study, PVA-gel beads were used in an expanded granular sludge blanket (EGSB) reactor to evaluate their effectiveness as biocarriers in treating EG. The parameters of EGSB, such as OLR, alkalinity, recycle rate, and 
trace elements, were investigated for the purpose of further application of this method.

\section{Methods EGSB}

The EGSB was made of acrylic resin and had a working volume of $3.9 \mathrm{~L}$ with a square cross-section of $36 \mathrm{~cm}^{2}$ and height of $110 \mathrm{~cm}$. Influent was continuously provided to the EGSB using a peristaltic pump. The reactor had six uniformly located sampling ports and a recirculation pump to adjust the level of bed expansion. The temperature was maintained at $35{ }^{\circ} \mathrm{C}$. Sampling ports were located at heights of 5, 20, 35, 50 and $65 \mathrm{~cm}$ above the reactor bottom. A gas-solid separator (GSS) with a simple structure was designed for the collection of generated biogas (Fig. 1). The biogas was separated by the GSS and collected using the method described by Wenjie et al. (2011).

\section{Inoculation and feeding media}

New PVA-gel beads with an average diameter of 3-4 mm were used. At first, in total $2.5 \mathrm{~L}$ of digester sludge and $0.95 \mathrm{~L}$ of PVA-gel were mixed in one tank with a sequence batch mode. Corn steep liquor (CSL) was used as feed.

After one month, the PVA-gel beads turned yellow in color compared to the white color of unused ones. This means that PVA-gel beads have good biomass affinity. The PVA-gel beads were then separated from the tank and introduced into the EGSB reactor whereby they contributed to about one quarter of the reactor volume. The reactor was started by using EG as influent with an initial COD concentration of about $500 \mathrm{mg} / \mathrm{L}$.

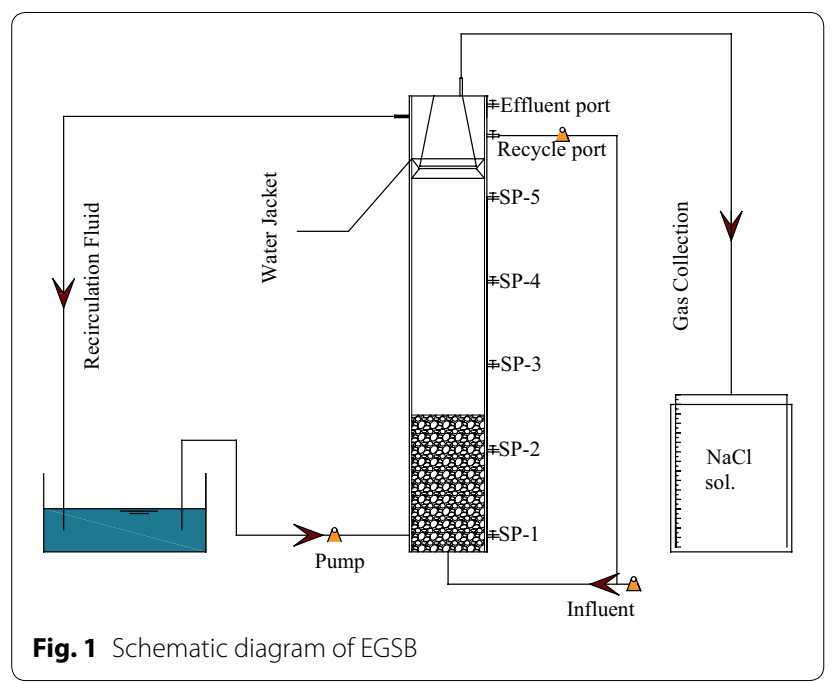

\section{Analytical methods}

COD, suspended solids (SS), volatile suspended solids (VSS), volatile fatty acids (VFAs), alkalinity: Filtered COD $(1 \mu \mathrm{m})$ were measured by the closed reflux colorimetric method (APHA 1995). SS and VSS in effluent and sludge samples were measured in accordance with Standard Methods (APHA 1995). Alkalinity levels in effluent samples were determined by titration (APHA 1995). VFAs were quantified by using a CTO-10AS liquid chromatograph (Shimadzu, Japan).

Biogas collection and analysis: Biogas was collected through GSS and the volume was measured using an inverted measuring cylinder containing tap water with the $\mathrm{pH}$ lowered to 3 using $1 \mathrm{~N} \mathrm{H}_{2} \mathrm{SO}_{4}$. Biogas analyses were performed using a $\mathrm{GC}-14 \mathrm{~B}$ gas chromatograph (Shimadzu, Japan).

PVA-gel characteristics: the settling velocity of PVAgel/granules was measured by the method of Wenjie et al. (2008). The amount of sludge (biomass or solids) attached to PVA granules (g VSS/g PVA gel) was determined by the wet weight difference from an average of 30 pairs of new (unused) and granulated PVA-gel.

Scanning electron microscopy (SEM): samples were first washed in a $0.1 \mathrm{M}$ phosphate buffer solution ( $\mathrm{pH}$ 7.4) for $5 \mathrm{~min}$. The samples were then hardened for $90 \mathrm{~min}$ in a $2.5 \%$ glutaraldehyde solution prepared with the buffer solution. Next, the samples were washed in the buffer solution three times for $10 \mathrm{~min}$ each and then fixed for $90 \mathrm{~min}$ in a $1.0 \% \mathrm{OsO} 4$ solution prepared with the buffer solution. After washing the samples three times for $10 \mathrm{~min}$ each in the buffer solution, they were dewatered for 10 min each in serially graded solutions of ethanol at concentrations of 10, 30, 50, 70, 90, and $95 \%$. SEM observations were conducted using a scanning electron microscope (JEOL, JSM-5310LV, Japan).

Methanogenic activity: the methanogenic activity tests were conducted on the PVA-gel beads from the UASB reactor using the method outlined by Wenjie et al. (2011). The tests were performed in one $3.9 \mathrm{~L}$ reactor with CSL substrates of equal COD $(5 \mathrm{~g} / \mathrm{L})$ in order to obtain total methanogenic activity.

\section{Results and discussion}

\section{Reactor performance}

The main operational parameters under various OLRs throughout the study are shown in Table 1 . The reactor was started with an OLR of $2.1 \mathrm{~kg} \mathrm{COD} / \mathrm{m}^{3} /$ day and a hydraulic retention time (HRT) of $6 \mathrm{~h}$. The influent COD level was increased stepwise to $3500 \mathrm{mg} / \mathrm{L}$ (the designed concentration) in 5 steps.

The reactor was operated continuously for a period of 133 days, during which time the OLR was maintained at $12-15 \mathrm{~kg} \mathrm{COD} / \mathrm{m}^{3} /$ day. In phases 6 and 7 , the 
Table 1 Summary of conditions used during operation of the EGSB reactor treating EG

\begin{tabular}{|c|c|c|c|c|c|c|c|}
\hline Phase & $\begin{array}{l}\text { Time } \\
\text { (days) }\end{array}$ & $\begin{array}{l}\text { OLR } \\
\left(\mathrm{kg} / \mathrm{m}^{3} / \text { day }\right)\end{array}$ & $\begin{array}{l}\text { Recycle rate } \\
\text { (L/h) }\end{array}$ & $\begin{array}{l}\mathrm{COD}_{\text {in }} \\
(\mathrm{mg} / \mathrm{L})\end{array}$ & $\mathrm{pH}_{\text {in }}$ & $\begin{array}{l}\text { Trace nutrients } \\
(\mathrm{ml} / \mathrm{L})\end{array}$ & $\begin{array}{l}\mathrm{NaHCO}_{3} \\
(\mathrm{mg} / \mathrm{L})\end{array}$ \\
\hline 1 & $0-14$ & $2.1 \pm 0.1$ & 25 & $523 \pm 35$ & $7.56 \pm 0.28$ & 7.50 & 200 \\
\hline 2 & $15-23$ & $4.5 \pm 0.1$ & 25 & $1121 \pm 36$ & $7.51 \pm 0.24$ & 7.50 & 400 \\
\hline 3 & $24-35$ & $9.8 \pm 0.3$ & 25 & $2453 \pm 64$ & $8.11 \pm 0.25$ & 7.50 & 880 \\
\hline 4 & $36-37$ & $12.0 \pm 0.0$ & 25 & $3004 \pm 0$ & $8.12 \pm 0.00$ & 7.50 & 1200 \\
\hline 5 & $38-50$ & $14.6 \pm 0.3$ & 25 & $3640 \pm 87$ & $8.02 \pm 0.30$ & 7.50 & 1400 \\
\hline 6 & $51-58$ & $13.4 \pm 0.7$ & 20 & $3360 \pm 183$ & $8.22 \pm 0.29$ & 7.50 & 1400 \\
\hline 7 & 59-75 & $13.2 \pm 2.7$ & 20 & $3304 \pm 686$ & $8.16 \pm 0.25$ & 3.75 & 1400 \\
\hline 8 & $76-98$ & $15.2 \pm 0.7$ & 15 & $3807 \pm 176$ & $7.84 \pm 0.27$ & 3.75 & 1000 \\
\hline 9 & 99-109 & $15.0 \pm 1.2$ & 15 & $3743 \pm 289$ & $7.62 \pm 0.15$ & 3.75 & 800 \\
\hline 10 & 110-129 & $14.0 \pm 1.0$ & 15 & $3497 \pm 256$ & $7.79 \pm 0.21$ & 3.75 & 600 \\
\hline 11 & 130-149 & $14.0 \pm 0.2$ & 15 & $3503 \pm 46$ & $7.89 \pm 0.23$ & 0 & 600 \\
\hline 12 & $150-168$ & $13.1 \pm 1.0$ & 15 & $3283 \pm 261$ & $7.68 \pm 0.17$ & 0 & 400 \\
\hline
\end{tabular}

recycle rate was reduced to $20 \mathrm{~L} / \mathrm{h}$, and from phase 8 , this value was reduced again to $15 \mathrm{~L} / \mathrm{h}$. In order to maintain the expanded PVA bed, a recycle rate of $15 \mathrm{~L} / \mathrm{h}$ must be applied. Thus, no further reduction of recycle rate was carried out in the study. In order to determine the appropriate quantity of added chemicals, the added trace nutrients were reduced to $3.75 \mathrm{ml} / \mathrm{L}$ in phase 7 and to 0 in phase 11 . In phases 8, 9, 10 and 12, the amounts of $\mathrm{NaHCO}_{3}$ added in the influent were 1000, 800, 600, and $400 \mathrm{mg} / \mathrm{L}$, respectively.

The COD removal rate reached a value higher than about $95 \%$ after about 1 month (Fig. 2). The influent COD was then stepwise increased from $500 \mathrm{mg} / \mathrm{L}$ to $3500 \mathrm{mg} / \mathrm{L}$ in 5 phases. The HRT was maintained at $6 \mathrm{~h}$. After that, the recycle rate, buffer, and nutrients were reduced. There was only a slight change in removal rate as shown in Fig. 2. A stable COD removal rate of about $96 \%$ could be maintained. The EGSB used in this study behaved just like a perfectly mixed reactor in which there is a gas solid separator to retain solids in the reactor.

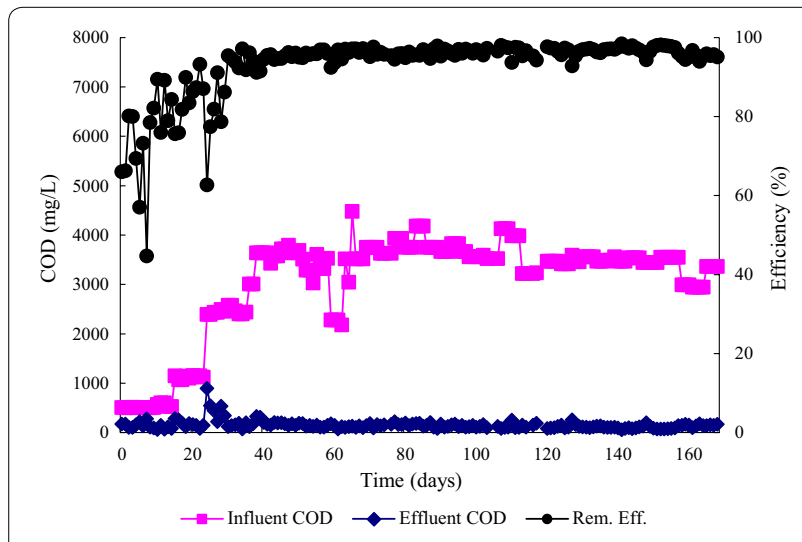

Fig. 2 Changes in COD removal for EGSB reactor
Therefore, reduction of recycle rate from 20 to $15 \mathrm{~L} / \mathrm{h}$ had no appreciable effect upon reactor performance.

The organic loading removal rate was also very good. A value of almost $100 \%$ could be achieved as shown by the linear regression line with a reliable value of about $99 \%$ (Fig. 3). The removal rate decreased slightly when the OLR was less than $10 \mathrm{~kg} \mathrm{COD} / \mathrm{m}^{3} /$ day, but soon recovered. This means the proliferation of the bacteria in the EGSB reactor was very fast. Due to the degradability of EG, the concentration had a greater effect on removal rate than HRT.

The effluent VFA, mainly in the form of acetate, was detected when the influent COD was increased (Fig. 4). Propionate was also occasionally detected but at a concentration below $20 \mathrm{mg} / \mathrm{L}$.

The biogas production volume was calculated according to the collected biogas in one set time. A biogas production yield rate of $0.24 \mathrm{~m}^{3} / \mathrm{kg}$ COD was achieved in this study (Fig. 5). The $\mathrm{CH}_{4}$ and $\mathrm{CO}_{2}$ contents were stable during the experiment period.

Changes in total nitrogen (TN) and total phosphorus (TP) removal are shown in Figs. 6 and 7, respectively. The TN removal efficiency could reach $20 \%$ on average. There was no obvious change even when the amount of $\mathrm{NaHCO}_{3}$ added was reduced. On day 59, the trace elements were reduced to $3.75 \mathrm{ml} / \mathrm{L}$. TP removal decreased from 80 to $20 \%$ on average. This indicated that precipitation of orthophosphate might contribute to the TP removal.

\section{PVA-gel development}

Figure 8 shows an SEM photo of the PVA-gel obtained in the EGSB reactor. The surface of the PVA-gel beads was covered with dense sludge. A few large cavities were found with small cavities distributed all over the surface 


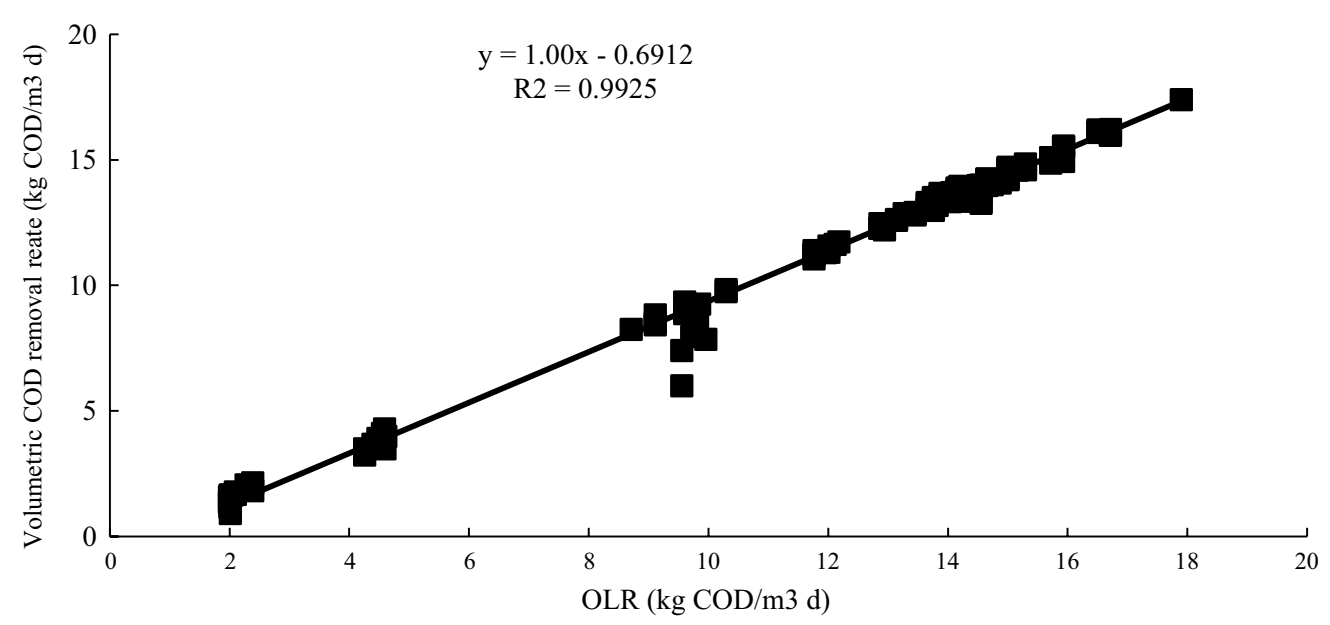

Fig. 3 Relationship between OLR and volumetric COD removal rate

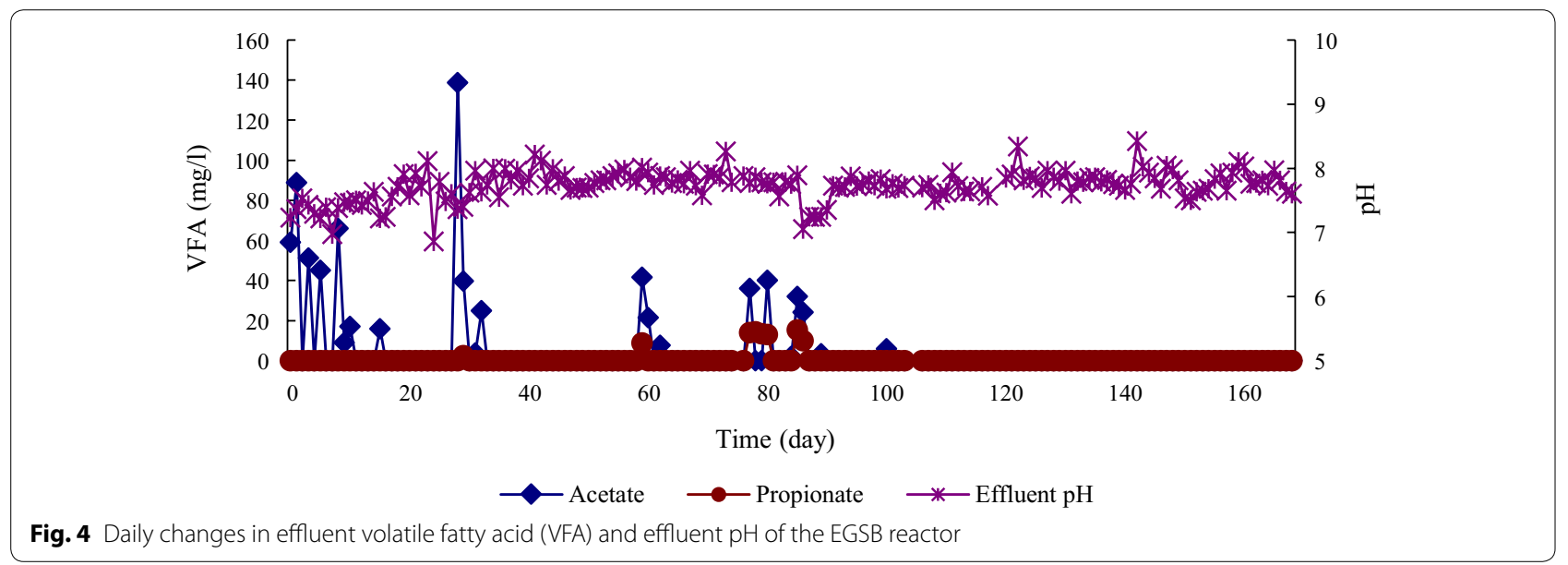

for biogas production. The PVA-gel had higher biomass attachment due to the hydraulic conditions of EGSB reactor, which could be proved by the cracks on the surface. Also, the inner part of the PVA-gel beads was observed to be filled with bacteria as shown in Fig. 8.

The bacteria attached to the PVA-gel were composed of a heterogeneous population including short and long rods, cocci and filaments (Fig. 9). The microbial structures on the PVA-gel found in the EGSB reactor were a little different from those in the UASB reactor. A large number of long rod-shaped bacteria (Methanosaeta), were found. Low acetate concentration was found in the EGSB reactor, and low acetate concentration was beneficial for long shaped bacteria growth.

At first the PVA-gel beads were white in color. After 1 month of cultivation, the color changed to yellow. At the end of this study, the color of the PVA-gel beads turned completely black (Fig. 10).
The matured black PVA-gel beads had an average settling velocity of $168 \mathrm{~m} / \mathrm{h}(5 \mathrm{~cm} / \mathrm{s})$ and $0.83 \mathrm{~g} \mathrm{VSS} / \mathrm{g}$ PVA gel. Compared with the results of the UASB reactor, the settling velocity decreased following the biomass attachment.

The parameters of the UASB and EGSB reactor treating CSL and EG are shown in Table 2. The mixing condition for the EGSB reactor was better than that of the UASB reactor due to the internal recycling. For EGSB reactor, with a higher influent $\mathrm{COD}$, shorter HRT, and higher OLR, a better COD removal efficiency could be achieved. The amount of biomass attached to the PVAgel increased significantly, especially for treating EG. The specific bacteria in the UASB reactor was mainly composed of Methanosarcina, but in the EGSB reactor Methanosaeta also contributed to a large part.

Compared to the results of the UASB, the cultivated PVA-gel could function well with a shorter HRT 


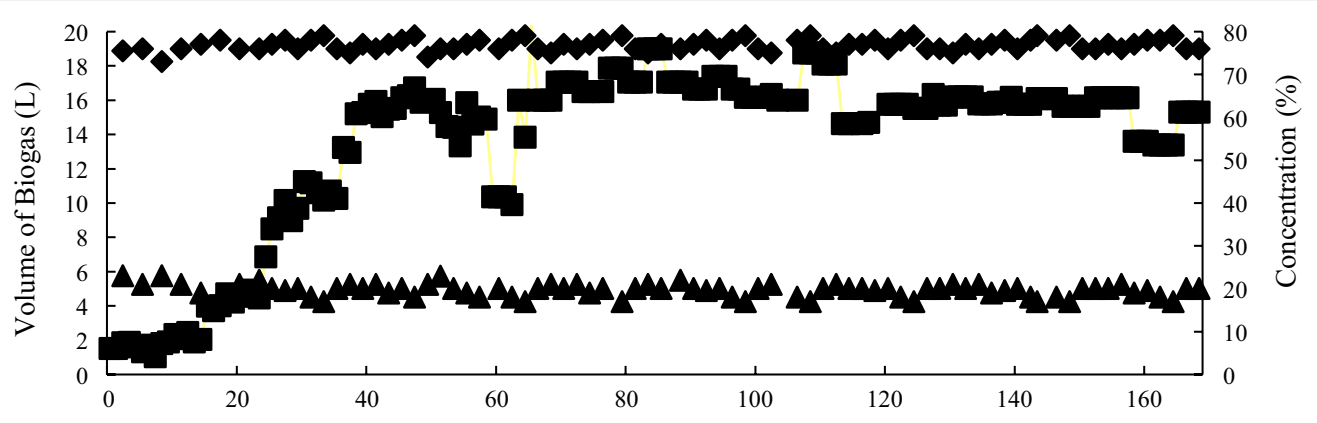

Time (days)

- Gas volume (1) $\neg$ Methane Con. (\%) $\neg$ CO2 Con. (\%)

Fig. 5 Daily changes in biogas production of EGSB reactor

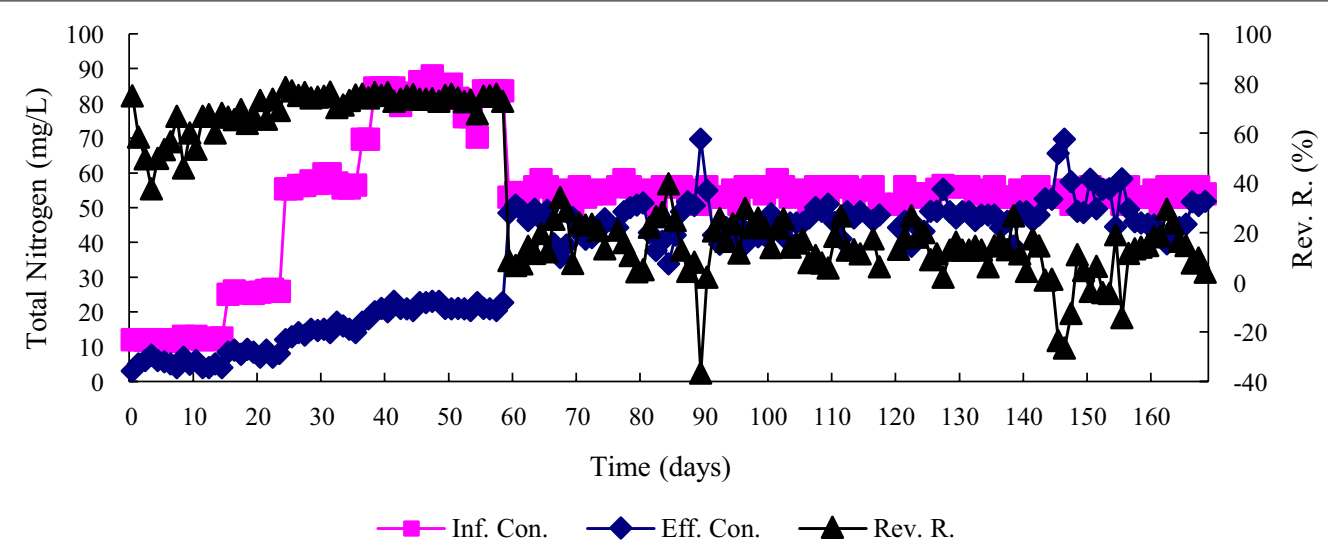

Fig. 6 Daily changes in TN removal

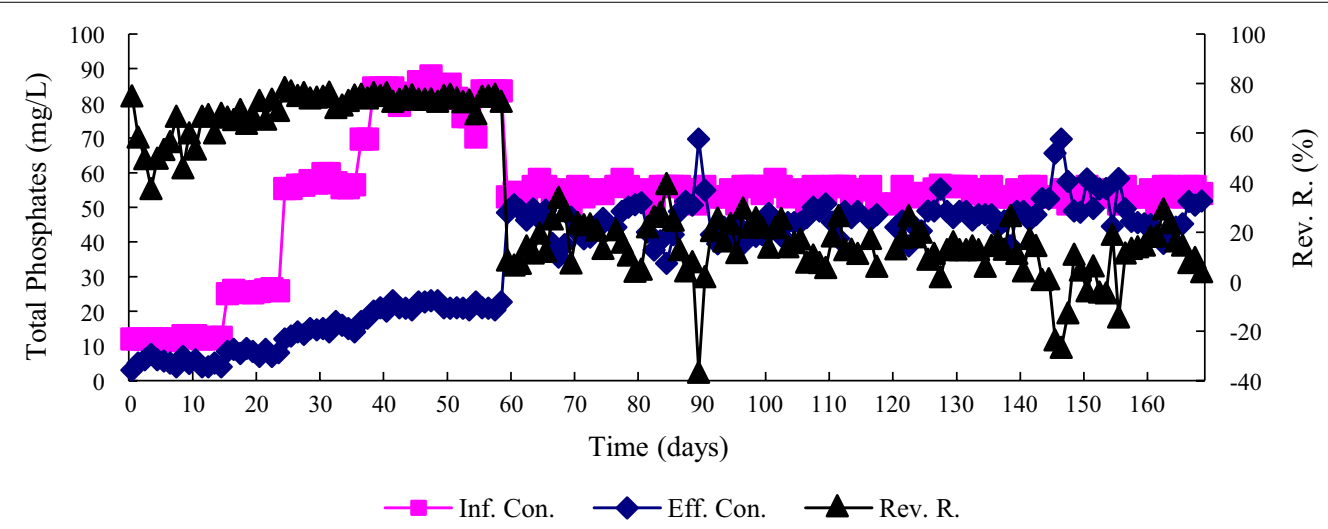

Fig. 7 Daily changes in TP removal

and higher OLR due to the higher amount of biomass attached to the PVA-gel beads. Furthermore, the specific bacteria Methanosarta was confirmed in the EGSB reactor, which indicated that the mixing condition was better in the EGSB reactor, and the COD level in the reactor was lower.

According to the COD concentration profiles throughout the depth of the reactor, only about $40 \mathrm{mg} / \mathrm{l} \mathrm{COD}$ 

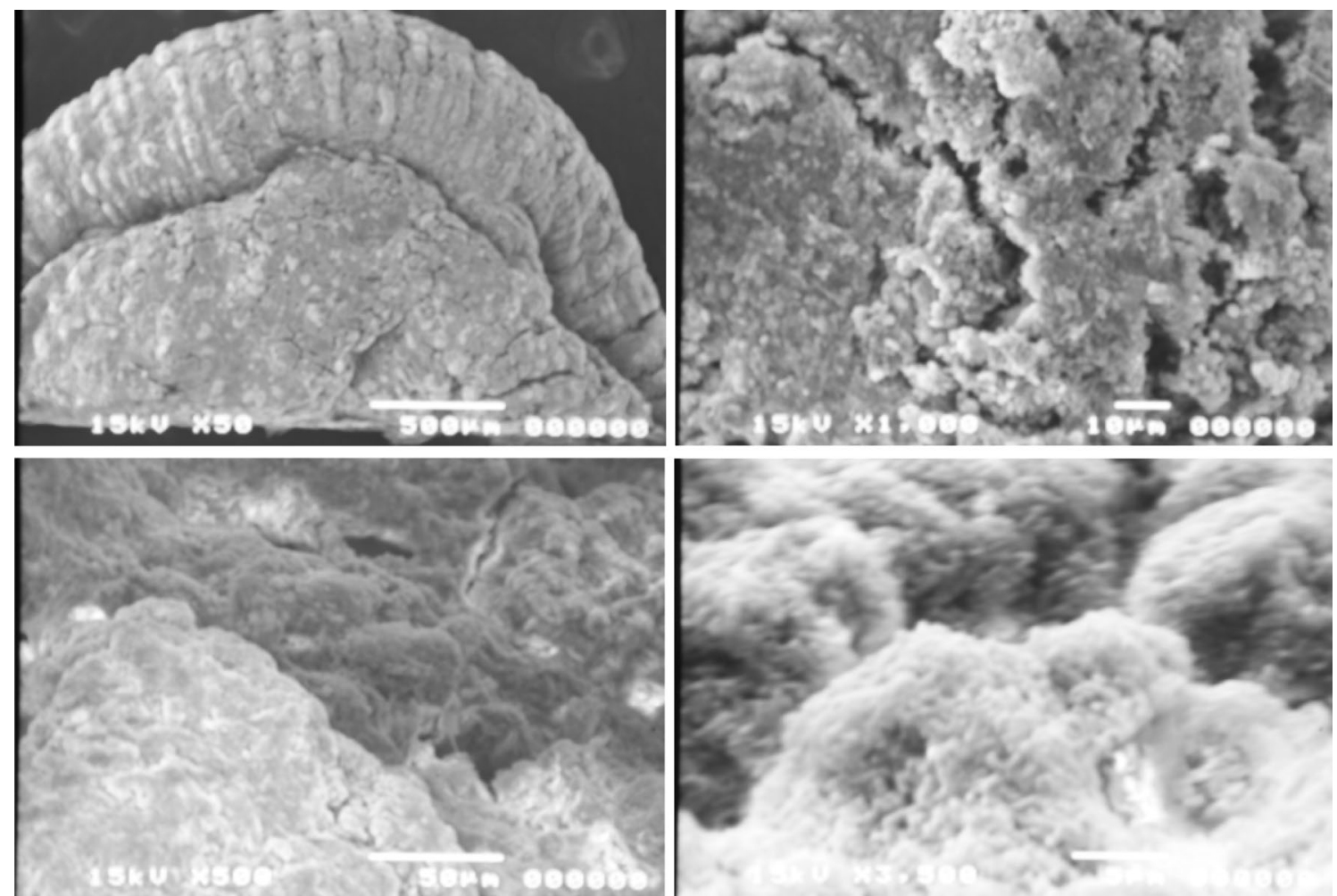

Fig. 8 SEM photos of the PVA-gel from EGSB reactor
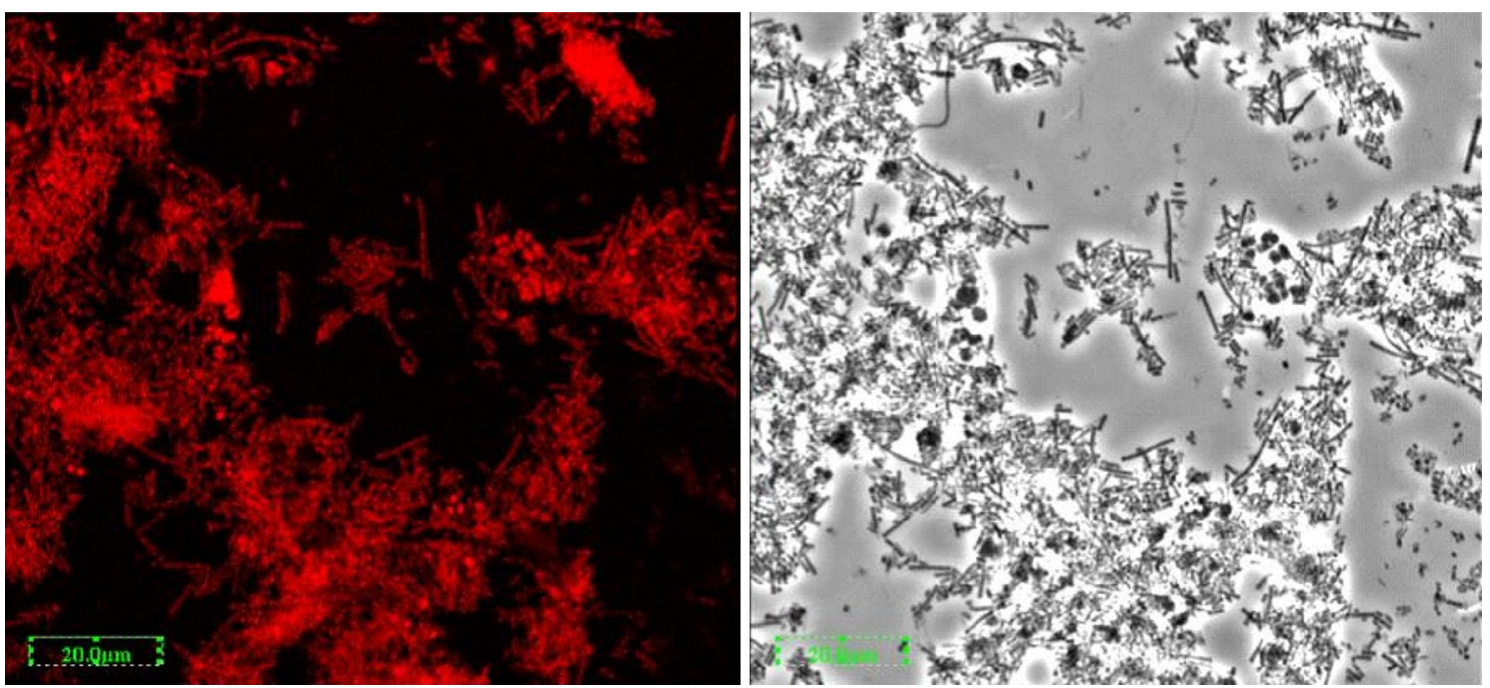

Fig. 9 FISH photos of the bacteria attached on the PVA-gel

was removed from the upper part of the reactor (above $50 \mathrm{~cm}$ ). It can be concluded that the EG was most degraded by the PVA-gel layer. At the end of the experiment, the concentrations of the added trace nutrients and $\mathrm{NaHCO}_{3}$ were 0 and $400 \mathrm{mg} / \mathrm{L}$, respectively. Thus, it can be concluded that the PVA-gel in this study can function effectively as a biocarrier to retain enough sludge in the reactor due to the dilution effect. 


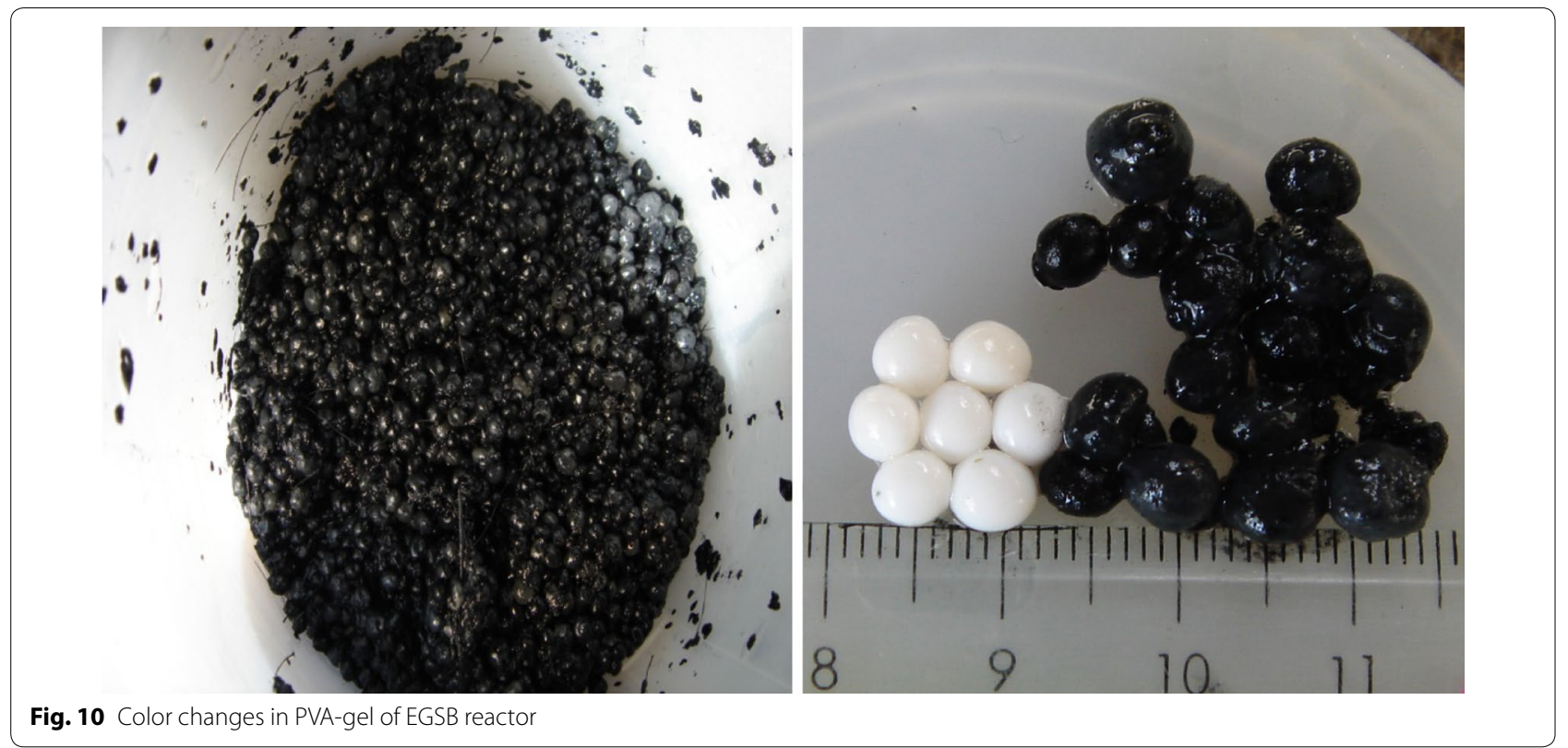

Table 2 Comparison of UASB and EGSB reactors treating different substrates

\begin{tabular}{|c|c|c|c|c|}
\hline \multirow[t]{2}{*}{ Parameter } & \multicolumn{2}{|l|}{ CSL } & \multicolumn{2}{|l|}{ EG } \\
\hline & UASB & EGSB & UASB & EGSB \\
\hline Mix condition & Bad & Good & Bad & Good \\
\hline Influent COD (mg/L) & 9100 & 12,900 & 1500 & 3283 \\
\hline $\mathrm{HRT}(\mathrm{h})$ & 8 & 6 & 8 & 6 \\
\hline OLR (kg/m3/day) & 22.5 & 27 & 11 & 16 \\
\hline COD removal efficiency (\%) & 90 & 92 & 95 & 97 \\
\hline Biomass attached (g MLSS/g PVA-gel) & 0.93 & 1.02 & 0.25 & 0.83 \\
\hline Specific bacteria & Methanosarcina & Methanosaeta & Methanosarcina & Methanosaeta \\
\hline
\end{tabular}

\section{Conclusions}

By using PVA-gel cultivated in one batch mode, it was possible to start an EGSB to treat EG. The COD removal efficiency could reach a value higher than $95 \%$ with an OLR of $15 \mathrm{~kg} \mathrm{COD} / \mathrm{m}^{3} /$ day. The influent COD was about $3500 \mathrm{mg} / \mathrm{L}$, which was almost the same as real wastewater for this application. Biogas production was about $0.3 \mathrm{~m}^{3} /$ $\mathrm{kg}$ COD with a methane concentration of $77 \%$. Compared with the results of the UASB reactor, the amount of biomass attached to the PVA-gel in the EGSB reactor was greater. SEM analysis experiment also showed that the inner part of the PVA-gel beads in the EGSB reactor was also filled by bacteria due to the high recycle rate.

\section{Authors' contributions}

YJ carried out the SEM and FISH studies, and drafted the manuscript. DW participated in the design of the study and performed the statistical analysis. WZ conceived of the study, and participated in its design and coordination and helped to draft the manuscript. All authors read and approved the final manuscript.

\section{Author details}

${ }_{1}^{1}$ Guangxi Key Laboratory of New Energy and Building Energy Saving, College of Civil Engineering and Architecture, Guilin University of Technology, 12, Jiangan Road, Guilin 541004, China. ${ }^{2}$ Guangxi Key Laboratory of Environmental Pollution Control Theory and Technology, Guilin University of Technology, Guilin 541004, China. ${ }^{3}$ Guangxi Collaborative Innovation Center for Water Pollution Control and Water Safety in Karst Area, Guilin University of Technology, Guilin 541004, China.

\section{Acknowledgements}

This research was supported by the Guangxi Natural Science Foundation (2014 GXNSFBA118265), the project of high level innovation team and outstanding scholar in Guangxi colleges and universities. The authors thank the thesis of "Application of PVA-Gel beads as biomass carrier for anaerobic wastewater treatment" by Wenjie Zhang, Kumamoto University.

\section{Competing interests}

The authors declare that they have no competing interests.

Received: 24 October 2015 Accepted: 24 May 2016

Published online: 23 June 2016 


\section{References}

APHA (1995) Standard method for the examination of water and wastewater, 19th edn. American Public Health Association, Washington, DC

Hassania AH, Borgheia SM, Samadyarb H, Ghanbaric B (2014) Utilization of moving bed biofilm reactor for industrial wastewater treatment containing ethylene glycol: kinetic and performance study. Environ Technol 35:499-507

Hulshoff Pol LW, de Castro Lopes SI, Lettinga G, Lens PNL (2004) Anaerobic sludge granulation. Water Res 38:1376-1389

Khanh D, Quan L, Zhang W, Hira D, Furukawa K (2011) Effect of temperature on low-strength wastewater treatment by UASB reactor using poly (vinyl alcohol)-gel carrier. Biores Technol 102:11147-11154
Wenjie Z (2008a) Applications of PVA-gel beads as biomass carrier for anaerobic wastewater treatment. Ph.D. thesis, Kumamoto University, Kumamoto, Japan. http://reposit.lib.kumamoto-u.ac.jp/handle/2298/11953

Wenjie Z, Dunqiu W, Yasunori K, Taichi Y, Li Z, Furukawa K (2008) PVA-gel beads enhance granule formation in a UASB reactor. Biores Technol 99:8400-8405

Wenjie Z, Qinglin X, Rouse JD, Qiao S, Furukawa K (2009) Treatment of highstrength corn steep liquor using cultivated polyvinyl alcohol gel beads in an anaerobic fluidized-bed reactor. J Biosci Bioeng 107:49-53

Wenjie Z, Xuehong Z, Dunqiu W, Yasunori K, Rouse JD, Furukawa K (2011) Trace elements enhance biofilm formation in UASB reactor for solo simple molecule wastewater treatment. Biores Technol 102:9296-9299

\section{Submit your manuscript to a SpringerOpen ${ }^{\circ}$ journal and benefit from:}

- Convenient online submission

- Rigorous peer review

Immediate publication on acceptance

- Open access: articles freely available online

- High visibility within the field

- Retaining the copyright to your article 